Nevada

Environmental

Restoration

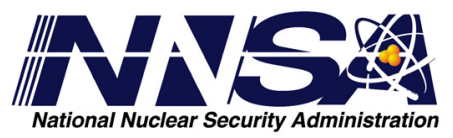

Project

\title{
Addendum to the Closure Report for Corrective Action Unit 427: \\ Area 3 Septic Waste Systems 2, 6, \\ Tonopah Test Range, Nevada
}

Controlled Copy No.:

Revision No.: 0

October 2008

Approved for public release; further dissemination unlimited.

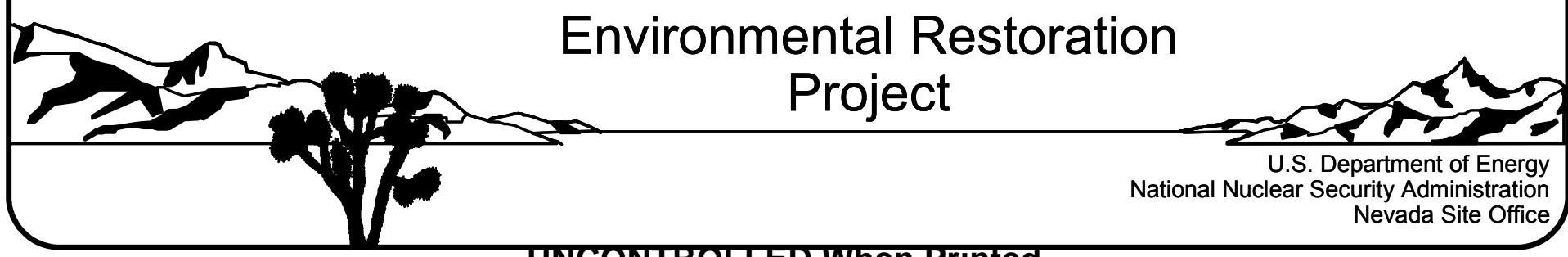


Available for public sale, in paper, from:

U.S. Department of Commerce

National Technical Information Service

5285 Port Royal Road

Springfield, VA 22161

Phone: 800.553 .6847

Fax: 703.605.6900

Email: orders@ntis.gov

Online ordering: http://www.ntis.gov/ordering.htm

Available electronically at $\underline{h t p: / / w w w . o s t i . g o v / b r i d g e ~}$

Available for a processing fee to U.S. Department of Energy and its contractors, in paper, from:

U.S. Department of Energy

Office of Scientific and Technical Information

P.O. Box 62

Oak Ridge, TN 37831-0062

Phone: 865.576 .8401

Fax: 865.576.5728

Email: reports@adonis.osti.gov

Reference herein to any specific commercial product, process, or service by trade name, trademark, manufacturer, or otherwise, does not necessarily constitute or imply its endorsement, recommendation, or favoring by the United States Government or any agency thereof or its contractors or subcontractors. 


\title{
ADDENDUM TO THE CLOSURE REPORT FOR CORRECTIVE ACTION UNIT 427: AREA 3 SEPTIC WASTE SYSTEMS 2, 6, TONOPAH TEST RANGE, NEVADA
}

\author{
U.S. Department of Energy \\ National Nuclear Security Administration \\ Nevada Site Office \\ Las Vegas, Nevada
}

Controlled Copy No.:

Revision No.: 0

October 2008

Approved for public release; further dissemination unlimited. 


\section{Addendum to the Closure Report for Removal of the Use Restriction}

This document constitutes an addendum to the April 1999, Closure Report for Corrective Action Unit 427: Area 3 Septic Waste Systems 2, 6, Tonopah Test Range, Nevada as described in the document Recommendations and Justifications for Modifications for Use Restrictions Established under the U.S. Department of Energy, National Nuclear Security Administration Nevada Site Office Federal Facility Agreement and Consent Order (UR Modification document) dated February 2008. The UR Modification document was approved by NDEP on February 26, 2008. The approval of the UR Modification document constituted approval of each of the recommended UR modifications. In conformance with the UR Modification document, this addendum consists of:

- This cover page that refers the reader to the UR Modification document for additional information

- The cover and signature pages of the UR Modification document

- The NDEP approval letter

- The corresponding section of the UR Modification document

This addendum provides the documentation justifying the cancellation of the URs for:

- CAS 03-05-002-SW02, Septic Waste System

- CAS 03-05-002-SW06, Septic Waste System

These URs were established as part of Federal Facility Agreement and Consent Order (FFACO) corrective actions and were based on the presence of contaminants at concentrations greater than the action levels established at the time of the initial investigation (FFACO, 1996; as amended August 2006).

Since these URs were established, practices and procedures relating to the implementation of risk-based corrective actions (RBCA) have changed. Therefore, these URs were re-evaluated against the current RBCA criteria as defined in the Industrial Sites Project Establishment of Final Action Levels (NNSA/NSO, 2006c). This re-evaluation consisted of comparing the original data (used to define the need for the URs) to risk-based final action levels (FALs) developed using the current Industrial Sites RBCA process.

The re-evaluation resulted in a recommendation to remove these URs because contamination is not present at these sites above the risk-based FALs. Requirements for inspecting and maintaining these URs will be canceled, and the postings and signage at each site will be removed. Fencing and posting may be present at these sites that are unrelated to the FFACO URs such as for radiological control purposes as required by the NV/YMP Radiological Control Manual (NNSA/NSO, 2004f). This modification will not affect or modify any non-FFACO requirements for fencing, posting, or monitoring at these sites. 
Nevada

Environmental

Restoration

Project

Recommendations and Justifications for Modifications for Use Restrictions Established under the U.S. Department of Energy, National Nuclear Security Administration Nevada Site Office

Federal Facility Agreement and Consent Order

Controlled Copy No.:

Revision No.: 0

February 2008

Approved for public release; further dissemination unlimited.

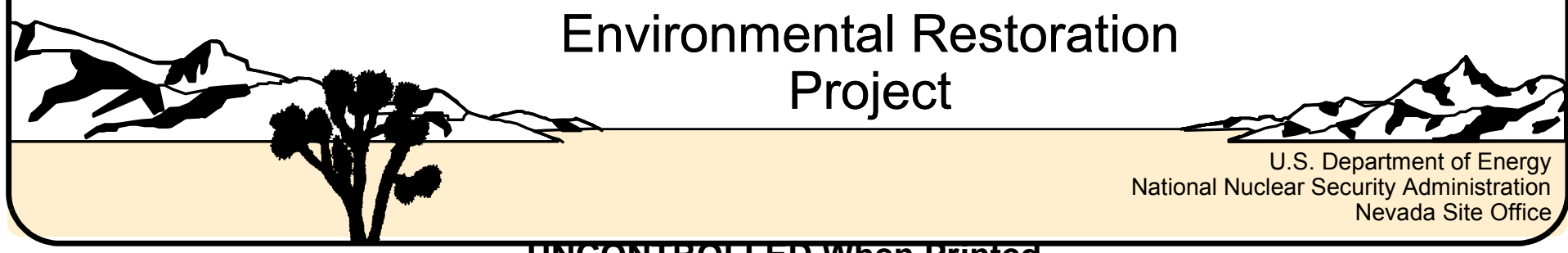


Recommendations and Justifications for Modifications for Use Restrictions Established under the U.S. Department of Energy, National Nuclear Security Administration Nevada Site Office Federal Facility Agreement and Consent Order

Approved by: /s/ Kevin J. Cabble

Date: $02 / 05 / 2008$

Kevin J. Cabble

Federal Sub-Project Director

Industrial Sites Sub-Project

Approved by:

/s/ John B. Jones

Date: $02 / 04 / 2008$

John B. Jones

Acting Federal Project Director

Environmental Restoration Project 
February 26, 2008

John B. Jones

Acting Federal Project Director

Environmental Restoration Project

National Nuclear Security Administration

Nevada Site Office

P. O. Box 98518

Las Vegas, NV 89193-8518

RE: Approval of Recommendations and Justifications for Modifications for Use Restrictions

Established under the U.S. Department of Energy, National Nuclear Security Administration, Nevada Site Office Federal Facility Agreement and Consent Order

Dear Mr. Jones:

The Nevada Division of Environmental Protection, Bureau of Federal Facilities (NDEP) staff has received and reviewed the February 2008 final report for Recommendations and Justifications for Modifications for Use Restrictions Established under the U.S. Department of Energy, National Nuclear Security Administration, Nevada Site Office. The NDEP approves the requested changes to the previously agreed upon use restrictions for those Corrective Action Sites (CASs) as described in the report.

Address any questions regarding this matter to either Ted Zaferatos at (702) 486-2850, ext. 234 , or me at (702) 486-2850, ext. 231.

Sincerely

\section{/s/ Tim Murphy}

\section{T.H. Murphy}

Chief

Bureau of Federal Facilities

$\mathrm{TZ}$

cc: $\quad$ E.F. DiSanza, WMP, NNSA/NSO

FFACO Group, PSG, NNSAINSO, Las Vegas, NV

David C. Loewer, DTRAVCXT1, M/S 645, Mercury, NV

W.R. Griffin, SNJV/DTRA, M/S 645, Mercury, NV

T.A. Thiele, NSTec, Las Vegas, NV

R.F. Boehlecke, SNJV, Las Vegas, NV

K. J. Cabble, ERP, NNSANSO, Las Vegas, NV

John Wong. Jeff MacDougall, Dennis Nicodemus, NDEP Las Vegas, NV 


\subsection{CAU 427, Area 3 Septic Waste Systems 2, 6 (TTR)}

\subsection{CAS Descriptions}

Corrective Action Unit 427 is comprised of the following two CASs located in Area 3 of the TTR:

- CAS 03-05-002-SW02, Septic Waste System

- CAS 03-05-002-SW06, Septic Waste System

The septic waste systems (located within the southwest portion of the Area 3 Compound) were installed to receive sanitary and industrial liquid wastes generated from site maintenance and other daily operations conducted at the Area 3 Compound. Corrective Action Site 03-05-002SW02 and CAS 03-05-002-SW06 will be referred to as Septic Waste System (SWS) 2 and 6 respectively. Septic Waste System 2 and 6 were in operation during different time intervals from 1960 through 1990. Process knowledge of early septic operations regarding disposal practices and composition of waste streams is limited (DOE/NV, 1998c).

The components associated with SWS 2 are the distal end of 1965-1975 leachfield; southern leg of post-1975 leachfield; outfall ends of tanks 33-6 and 33-12; leach beds and drainage ends of the central and northern legs and the distribution box associated with post-1975 leachfield; fork associated with 1965-1975 leachfield; and outfall end of septic tank 33-4. The 1965-1975 leachfield received liquid wastes from all of the contributing SWS 2 and SWS 6 discharge sources during this time period. The post-1975 leachfield was operational until the SNL-consolidated sewer upgrade effectively eliminated the discrete systems that had been in use in the Area 3 Compound (DOE/NV, 1998c).

The component associated with SWS 6 is the pre-1965 leachfield. This is the earliest of the three leachfields at CAU 427 and was installed with the apparent intent to receive liquid wastes from Building 03-60 from 1960 through 1965. A video survey of the active line from Building 03-60 showed no tie-ins, off-shoots, or other irregularities (DOE/NV, 1998c).

\subsection{Current Use Restriction Description}

The future use of any land affected by this UR is restricted from any DOE or Air Force activity that may alter or modify the containment control, as approved by the state and identified in the CAU CR or other CAU documentation, unless appropriate concurrence is obtained in advance (DOE/NV, 1999b). 
Subsurface metal plates were placed at the corners of each use restricted area to simplify boundary detection (using a magnetometer or equivalent) while minimizing marker deterioration due to placement in high-traffic areas. The need for unobstructed road access prompted the placement of warning signs in low-traffic areas and subsurface boundary markers ( $1 \mathrm{ft} b g s)$ in high-traffic areas (DOE/NV, 1999b).

Annual inspections were to be performed for five years after the completion of closure activities, and documented on inspection forms. Site inspections will document indications of subsidence, erosion, and unauthorized use of soil and asphalt covers. Inspections will document the condition of markers and warning signs. Site monitoring will be used to determine whether maintenance, repairs, and/or modifications to UR administrative controls are needed and/or if termination of post-closure inspections can be proposed (DOE/NV, 1999b). Although no longer required, annual monitoring is still conducted at the site as a BMP (Murphy, 2006).

\subsection{Basis for Current Use Restriction}

Samples collected from the Area 3 SWS 2 and 6 were submitted for total VOCs, total SVOCs, TPH (gasoline and diesel/waste oil), total RCRA metals, total PCBs, and gamma spectroscopy analyses. Results from these analyses identified TPH (waste oil) and arsenic as the only contaminants exceeding PALs. The concentrations of arsenic above the PAL of $2.7 \mathrm{mg} / \mathrm{kg}$ were within the range considered representative of ambient conditions at the site. Therefore, arsenic is not considered to be a basis for this UR. Radiological results from the samples collected from SWS 2 and 6 locations did not exceed PALs (radiation distinguishable from background activities). Of 120 samples, 15 contained TPH as waste oil at concentrations above the PAL of $100 \mathrm{mg} / \mathrm{kg}$. These concentrations are associated with the northern and central distribution lines and the distribution box of the post-1975 leachfield, the proximal end of the 1965-1975 leachfield, and the outfall end of septic tank 33-4. Total petroleum hydrocarbons concentrations above the PAL of $100 \mathrm{mg} / \mathrm{kg}$ are limited laterally to the confines of the two discovered leach systems and have exhibited a low degree of vertical migration, with very few elevated levels, at depths up to $27.5 \mathrm{ft}$ bgs. No VOCs or SVOCs were detected above PALs (DOE/NV, 1998c).

Table 25-1 contains analytical results of all COCs at CAU 427 that are the basis for the current UR. The sample matrix for all samples is soil. 
Table 25-1

Sample Results for COCs at CAU 427

Used To Establish Current Use Restriction

\begin{tabular}{|c|c|c|c|}
\hline \multirow{2}{*}{$\begin{array}{c}\text { Sample } \\
\text { Location/Borehole }\end{array}$} & \multirow[b]{2}{*}{ Sample ID } & \multirow{2}{*}{$\begin{array}{c}\text { Sample Depth } \\
\text { (ft bgs) }\end{array}$} & Waste Oil \\
\hline & & & $\begin{array}{c}\text { PAL } \\
100 \mathrm{mg} / \mathrm{kg}\end{array}$ \\
\hline LF1-T1 & TTR00867 & 4.6 & 120 \\
\hline \multirow{3}{*}{$\begin{array}{l}\text { LF2-T1 \& LF2-T1- } \\
\text { Cutback }\end{array}$} & TTR00871 & 5.5 & 2,400 \\
\hline & TTR00874 & 6.0 & 1,600 \\
\hline & TTR00878 & 10.0 & 680 \\
\hline LF3-T1 & TTR00885 & 5.5 & 370 \\
\hline \multirow{2}{*}{ LF4-T1 } & TTR00887 & 6.0 & 230 \\
\hline & TTR00898 & 7.0 & 1,500 \\
\hline Tank 33-4 & TTR00929 & 5.0 & 2,900 \\
\hline Tank 33-4-SB & TTR00945 & 10.0 & 1,300 \\
\hline LF4-DBOX-SB & TTR00966 & 7.5 & 560 \\
\hline LF4-T1-20.0SEEP-SB & TTR00975 & 10.0 & 140 \\
\hline \multirow{3}{*}{$\begin{array}{c}\text { LF4-T1- } \\
\text { 40.0SEEP(U/G)-SB }\end{array}$} & TTR00990 & 12.5 & 180 \\
\hline & TTR00991 & 17.5 & 330 \\
\hline & TTR00993 & 27.5 & 1,100 \\
\hline Tank 33-5 & $\begin{array}{l}\text { TTR0931, } \\
\text { TTR0933 }\end{array}$ & 7.4 & 610 \\
\hline
\end{tabular}

bgs $=$ Below ground surface

$\mathrm{ft}=$ Foot

$\mathrm{mg} / \mathrm{kg}=$ Milligrams per kilogram

ID = Identification

$\mathrm{PAL}=$ Preliminary action level

\subsection{Basis for Use Restriction Modification}

The revised FALs associated with the TPH contamination were established based on the PALs of hazardous constituents of TPH diesel as described in Section 2.2.2. Hazardous constituents of TPH diesel were not detected in any of the samples at concentrations greater than their respective PALs (DOE/NV, 1998c). Therefore, no contaminants are present at this site in concentrations exceeding the revised FALs, and all revised FALs were established at the PAL concentrations.

\subsection{Proposed Modification}

Remove the FFACO UR, associated fencing and postings, and inspection and maintenance requirements from this site. 


\section{References}

DOE/NV, see U.S. Department of Energy, Nevada Operations Office.

FFACO, see Federal Facility Agreement and Consent Order.

Federal Facility Agreement and Consent Order. 1996 (as amended). Agreed to by the State of Nevada; U.S. Department of Energy, Environmental Management; U.S. Department of Defense; and U.S. Department of Energy, Legacy Management.

Murphy, T.H., Nevada Division of Environmental Protection. 2006. Letter to J.B. Jones, (DOE/NV) entitled, "NNSA/NSO Request to Reduce the Frequency of Post-Closure Monitoring of Corrective Action Units (CAU) 400, 404, 407, 423, 424, 426, 427, 453, and 487 at Tonopah Test Range (TTR), Nevada," 5 December. Las Vegas, NV.

NNSA/NSO, see U.S. Department of Energy, National Nuclear Security Administration Nevada Site Office.

U.S. Department of Energy, National Nuclear Security Administration Nevada Site Office. 2004f. NV/YMP Radiological Control Manual, DOE/NV--11718-079, Rev. 5. Prepared by Bechtel Nevada. Las Vegas, NV.

U.S. Department of Energy, National Nuclear Security Administration Nevada Site Office. 2006c. Industrial Sites Project Establishment of Final Action Levels, Rev. 0, DOE/NV--1107. Las Vegas, NV.

U.S. Department of Energy, Nevada Operations Office. 1998c. Corrective Action Decision Document for Corrective Action Unit 427: Area 3 Septic Waste Systems 2 and 6, Tonopah Test Range, Nevada, Rev 0, DOE/NV--509, UC-700. June. Las Vegas, NV.

U.S. Department of Energy, Nevada Operations Office. 1999b. Closure Report for Corrective Action Unit 427: Area 3 Septic Waste Systems 2 and 6, Tonopah Test Range, Nevada, DOE/NV--561. August. Las Vegas, NV. 


\title{
Library Distribution List
}

\author{
$\underline{\text { Copies }}$ \\ U.S. Department of Energy \\ 1 (Uncontrolled, electronic copy) \\ National Nuclear Security Administration \\ Nevada Site Office \\ Technical Library \\ P.O. Box 98518, M/S 505 \\ Las Vegas, NV 89193-8518 \\ U.S. Department of Energy \\ Office of Scientific and Technical Information \\ 1 (Uncontrolled, electronic copy) \\ P.O. Box 62 \\ Oak Ridge, TN 37831-0062 \\ Southern Nevada Public Reading Facility \\ 2 (Uncontrolled, electronic copies) \\ c/o Nuclear Testing Archive \\ P.O. Box 98521, M/S 400 \\ Las Vegas, NV 89193-8521 \\ Manager, Northern Nevada FFACO \\ 1 (Uncontrolled, electronic copy) \\ Public Reading Facility \\ c/o Nevada State Library \& Archives \\ 100 N Stewart Street \\ Carson City, NV 89701-4285
}

